\title{
FEMALE LABOR SUPPLY AND CHILD CARE IN FRANCE
}

\author{
PHILIPPE CHONÉ \\ DAVID LE BLANC \\ ISABELLE ROBERT-BOBÉE
}

\section{CESIFO WORKING PAPER NO. 1059 \\ CATEGORY 4: LABOUR MARKETS \\ OCTOBER 2003}

Presented at Venice Summer Institute, Workshop on Tax Policy and Labour Market Performance, July 2003

\footnotetext{
An electronic version of the paper may be downloaded - from the SSRN website: Www.SSRN.com

- from the CESifo website: www.CESifo.de
} 


\title{
FEMALE LABOR SUPPLY AND CHILD CARE IN FRANCE
}

\begin{abstract}
We use French household data to estimate a structural model of female labor supply and use of paid child care outside the home. Child care costs are found to have little impact on the labor market participation decision of mothers. The model is used to study various policy issues. The influence of the current tax credit on child care expenditures on the mothers' labor supply is weak. Suppressing the APE (Parental Allowance for the Education) would cause the female participation rate in our sample to rise by 4 points and the proportion of mothers using paid care to rise by 2 points. The responses of women to policy changes are very heterogenous. Macroeconomic changes in female labor supply are equally due to switches between non-participation and participation and switches between working hours by working women.
\end{abstract}

JEL Classification: J13, J22, H31, C15.

Keywords: female labor supply, child care, welfare participation, fiscal policy.

Philippe Choné Insee

Division enquêtes et études démographiques

Timbre F170

18 bv A. Pinard

75675 Paris Cedex 14

France
David le Blanc

Insee

Division enquêtes et études démographiques

Timbre F170

18 bv A. Pinard

75675 Paris Cedex 14

France

Isabelle Robert-Bobée

Insee

Division enquêtes et études démographiques

Timbre F170

18 bv A. Pinard

75675 Paris Cedex 14

France

isabelle.robert-bobee@insee.fr

We thank Holger Bonin, Denis Fougère, Guy Laroque, Lene Mejer, Françoise Maurel, Bernard Salanié, Béatrice Sédillot, and participants in seminars at CREST, Boston College, Boston University, Nantes University, Toulouse University, the CEPR-ECB meeting on labour supply in Frankfurt, the 2003 JMA meeting in Montpellier, the 2003 CESifo Venice Summer Institute on Tax Policy and Labour Market Performance and the 2003 European Econometric Society Meeting in Stockholm for useful comments. Remaining errors are ours. 


\section{Introduction}

In 2001, 3,4 million French households had children less than 7 years old and 2 million had children under 3 . The main financial incentives devoted to them are subsidies to reduce care costs and payment of a replacement income to mothers in case of temporary withdrawal from the labor market.

This study aims at modeling the simultaneous decisions of mothers of young children as regards labor supply (participation decision and choice of working hours) and use of formal paid child care (paid and not underground) outside parents' home. The model is used to analyze the impact of those policies on those decisions.

In a seminal article, Heckman (1974) showed that an increase in child care costs reduces both the probability that the mother works and the number of hours supplied when she works. Following work has encompassed a large variety of behavioral assumptions and used various data sources. However, the impacts of financial constraints on the decisions of mothers as regards participation and child care arrangements remain rather poorly known, as no clear consensus emerges from the empirical literature. In particular, estimates of elasticities of paid child care use, labor market participation and hours worked with respect to child care costs greatly vary along studies and conclusions vary quite a lot as regards potential effects of public policies. Moreover, comparisons between studies are difficult, due to the use of different fields.

Cleveland and Hyatt (1993) model the choice of the child care arrangement, conditional on the labor market participation of the mother. The options of child care arrangements then play a major role. Averett et al. (1997) and Blau and Hagy (1998) distinguish finely between the various types of child care. To deal with the endogeneity of employment decisions, Connelly and Kimmel (2000) add a participation predictor to the covariates of the discrete choice model for the type of child care arrangement. This strategy does not allow to simulate the effect of new subsidies to child care costs on female participation. In contrast, Blau and Hagy (1988) and Powell (2002) estimate a joint model of participation and use of child care arrangements. Finally, Ribar (1995) and Blundell et al. (2000) also model the intensive decision (choice of hours worked).

Most of the datasets used in the empirical studies on American and Canadian data include unit prices of child care arrangements. An exception is Ribar (1995) whose data comprise total expenditures on child care, but no information on either unit price or on quantity.

All the studies find a significantly positive impact of the mother's wage on participation $\square$. The elasticities of paid child care costs are also very different across studies. Ribar (1995) presents estimates ranging from -0.2 to -0.7 . The value is -0.34 according to Blau and Hagy (1998). Powell (2002) presents price elasticities of the various child care arrangements of about 1 for day-care centers and -3 for childminders in their home. Concerning the impact of wages on the use of a paid care arrangement, the corresponding elasticity is 0.18 according to Cleveland et al. (1996), and ranges from 0.1 to 0.8 in Ribar (1995). Finally, estimates of the elasticity of

\footnotetext{
1 As an example, estimates of the uncompensated wage elasticity of participation reported by Powell (2002) and Ribar (1995) are respectively 0.8 and from 0.1 to 0.5 according to the specification. Averett et al. (1997) present estimates of the wage elasticity of the number of hours worked ranging between 1 and 1.5 following the models.
} 
participation to child care costs are very variable ${ }^{2}$. As regards the elasticity of worked hours, Averett et al. (1997) present a high figure of -0.78; in contrast, Michalopoulos et al. (1992) estimate this elasticity close to zero.

We are also interested in results concerning the effects of the U.S. Child and Dependent Care TaxCredit (CDCTC), which is the main public device of income assistance to child care in

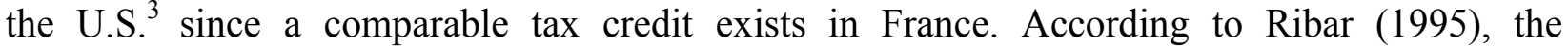
suppression of the CDCTC would have a tiny effect on female labor supply, since the participation rate of mothers of children less than 15 years old would only drop from $52.6 \%$ to $52.1 \%$. Ribar does not predict massive transitions from full-time to part-time jobs either. On the contrary, according to Averett et al. (1997), suppressing the CDCTC would have a big positive effect on the number of hours worked by young mothers. One cause of this divergence undoubtedly lies in the use of different methodologies and data sources.

From this brief review, it seems that no a priori belief concerning the magnitude of the effects of policies implemented in France can be gained from studies made on U.S. data. Turning to the French side, two studies may serve as guidelines. Piketty (1998) uses a change in the benefit system as a natural experiment to calculate labor supply elasticities of mothers of children under 3. In 1994, the Parental Allowance for Education (APE in French), which consists in giving a subsidy to parents withdrawing from the labor market until their child reaches the age of 3 , was extended to parents of two children. Among the newly eligible women, a sharp drop in the participation rate followed. Piketty (1998) estimates that $17 \%$ of the eligible women did drop out of the labor force as a consequence of the APE extension. Laroque and Salanié $(2000,2002)$ study the effects of financial incentives on the female labor supply. They use a methodology very comparable to ours and also use basically the same data, so that results from the two studies can be compared with confidence. However, they do not model child care use, so that we have no benchmark as regards estimates involving quantities related to child care.

In this paper, we estimate a structural model of participation, choice of working hours, and choice to use paid care outside the parental home, for mothers of children under 7 . We use data from the 1997 Labor Survey-Tax Return matched sample (see section 2 below). Due to the nature of our data, which does not allow for a breakdown of child care expenditures into prices and quantities, we rely heavily on Ribar's (1995) work ${ }^{4}$. However, two improvements are made. Firstly, we adopt a different parameterization of unobserved heterogeneity, which allows us to give a more satisfactory treatment of the observed situations. Secondly, we undertake joint estimation of all the equations. It allows us to recover correlations between unobserved tastes and residuals in the wage and child care expenditure equations. In comparison to most existing studies, our modeling of the tax and benefit system is far more precise. For example, we take into account the constraints on the labor supply of women imposed by the existence of a minimum wage. This complexity has a reward, since it allows us to examine many policy issues, from a change in the schedule of the French Child Care Tax Credit to changes in welfare provisions

\footnotetext{
${ }^{2}$ Blau and Robins (1988), Cleveland et al. (1996), Connelly (1992), Ribar (1995), Powell (1997), Blau and Hagy (1998), Michalopoulos and Robins (2000) present estimates that vary from -0.39 to -0.2 following the specifications and the fields considered.

${ }^{3}$ Depending on the parents' income, this subsidy can cover $20 \%$ to $30 \%$ of the child care expenditures of eligible households. See Averett et al. (1997) or Ribar (1995) for more details.

${ }^{4}$ Andrén makes a similar choice for studying the case of single mothers in Sweden.
} 
concerning reduction of working time by young mothers. To the pest of our knowledge, comparable results on French data did not exist before the present study ${ }^{6}$.

The remainder of the article is organized as follows; section 2 is devoted to the description of our data, section 3 presents the main provisions of the French tax and benefit system related to child care and labor supply of young mothers and section 4 presents the economic model and the econometric specification. Estimation results as well as policy simulations are discussed in sections 5 and 6 respectively and section 7 concludes.

\section{The data}

We use the 1997 Labor Force Survey-Tax Return matched sample conducted by Insee and Fiscal Services (DGI). These matched data combine the main advantage of the Labor Force Survey, i.e. a large representative sample of households with a rich set of demographic descriptors of the households for March 1997 and March 1998, to detailed information on the household's members' taxable incomes in the tax returns. The latter also contain information on child care expenditures during the year 1997 which are eligible for the Child Care Tax Credit. Information on child care expenditures coming from the tax files is likely to be more reliable than those obtained by direct interview because of recall problems of certain expenditures and of an uncertainty concerning the way in which the households take into account the government subsidies. In contrast, the tax data do not allow assessing the various child care arrangements to which the household resorts. Moreover, we do not have information on the number of hours of care, nor on the unit price of care arrangements.

\subsection{Sample selection}

Our field of investigation consists of couples having at least one child under the age of 7 (i.e., born in 1991 or afterwards). Child care expenditures of households having only older children are far lower because schooling is mandatory for children over 6 years old in France.

We focus on formal (paid and not underground) child care arrangements outside the household's home (mainly day-care centers and childminders in their home). The income tax return also contains information about wages paid by the household to employees working at the household's home. However, no information allows us to assess the precise nature of the services produced by these employees (taking care of children or housework for instance). We thus exclude from the sample households, which reported expenditures for an employee at home, exceed care expenditures outside the home. This exclusion results in slightly decreasing the average standard of living of the households and the share of the women working full-time.

The joint modeling of the mothers' labor supply and use of paid child care requires the construction of the budget constraint of the households, which involves the whole schedule of the tax and benefit system. We exclude nonmarried couples from our sample. Indeed, married couples fill in a joint tax return, whereas each partner of a nonmarried couple is a distinct fiscal unit. For nonmarried couples, children can be included in either tax returns, which involves

\footnotetext{
${ }^{5}$ Recent descriptive studies of child care arrangements and labor supply of mothers in France include Flipo and Sédillot (2000) and Robert-Bobée (2002). Lanot and Robin (1997) estimate a structural model of female participation with variable participation costs. However, they model the tax system by piecewise linear constraints and do not take the welfare system into account. Guillot (1996) only crossed the two decisions without taking into account the fact that they may interfere, and his model cannot be used to estimated policies effects.
} 
complex problems of optimization. This selection has about no effect on the characteristics of the sample.

Working hours are known only for wage-earning women. This leads us to exclude selfemployed women (and also self-employed men). Women being teachers or professors are also excluded from the sample because of potentially significant measurement errors on their working time. Indeed, they seem frequently to declare a weekly duration of work which corresponds only to teaching hours. Keeping those observations would bring us to consider them as working parttime, whereas the majority of them indeed work full-time. These exclusions lead to decrease the proportion of high educated women in the sample.

Eventually, to be consistent with our theoretical framework, we delete from the sample the couples in which the wife's calculated hourly wage is below the legal minimum wage (Smic).

Table 1 presents the characteristics of our initial sample and the effects of the successive selections described above.

Table 1 : Effects of the Sample Selection on Some Variables

\begin{tabular}{|c|c|c|c|c|c|c|}
\hline & \multirow[b]{2}{*}{$\begin{array}{c}\text { All } \\
\text { couples } \\
\text { with } \\
\text { children } \\
\text { under } 7\end{array}$} & \multicolumn{5}{|c|}{ Successive selections } \\
\hline & & $\begin{array}{c}\text { Self- } \\
\text { employed }\end{array}$ & Teachers & $\begin{array}{l}\text { Households } \\
\text { using mostly } \\
\text { paid care at } \\
\text { home }\end{array}$ & $\begin{array}{c}\text { Non- } \\
\text { married } \\
\text { couples }\end{array}$ & $\begin{array}{c}\text { Women } \\
\text { reporting } \\
\text { hourly } \\
\text { wages } \\
\text { under the } \\
\text { Smic }\end{array}$ \\
\hline Sample size & 4375 & 3732 & 3508 & 3397 & 2758 & 2655 \\
\hline \multicolumn{7}{|c|}{ Mother's occupational status and working time (in \%) } \\
\hline Self-employed & 5.4 & III & $/ / /$ & /// & /// & /// \\
\hline Not working & 46.0 & 48.3 & 50.2 & 51.3 & 51.9 & 54.2 \\
\hline Working half-time & 9.8 & 10.0 & 8.0 & 7.9 & 7.9 & 6.8 \\
\hline Working $80 \%$ part-time & 10.4 & 11.0 & 10.5 & 10.3 & 10.2 & 9.9 \\
\hline Working full-time & 28.5 & 30.7 & 31.3 & 30.5 & 30.0 & 29.1 \\
\hline \multicolumn{7}{|c|}{ Mother's educational level (in \%) } \\
\hline$<$ baccalaureat & 59.2 & 61.3 & 64.9 & 66.9 & 66.0 & 65.7 \\
\hline Baccalaureat & 15.1 & 15.0 & 15.6 & 15.6 & 15.9 & 16.0 \\
\hline Baccalaureat+2 & 14.9 & 14.1 & 13.0 & 12.2 & 12.6 & 12.8 \\
\hline Higher level & 10.7 & 9.6 & 6.5 & 5.3 & 5.6 & 5.6 \\
\hline \multicolumn{7}{|c|}{ Mean equivalent income in euros per year, 1997} \\
\hline & 14,430 & 14,120 & 13,800 & 13,380 & 13,530 & 13,600 \\
\hline \multicolumn{7}{|c|}{ Main paid care arrangement* (in \%) } \\
\hline $\begin{array}{l}\text { Paid care outside the } \\
\text { parental home }\end{array}$ & 24.2 & 24.9 & 24.0 & 24.8 & 24.3 & 24.1 \\
\hline Paid care at home & 5.2 & 3.8 & 3.3 & II/ & /I/ & /// \\
\hline \multicolumn{7}{|c|}{ Average annual care expenditures for households using paid care arrangements (euros) } \\
\hline $\begin{array}{l}\text { Paid care outside the } \\
\text { parental home }\end{array}$ & 1,130 & 1,140 & 1,150 & 1,140 & 1,140 & 1,150 \\
\hline Paid care at home & 4,750 & 4,590 & 4,700 & II/ & II/ & II/ \\
\hline
\end{tabular}

Source: Insee and Fiscal Services 1997 Labor-Force-tax Return matched survey

\subsection{Construction of the endogenous variables}

We define the situation of the woman on the labor market in 1997 as the occupation most frequently reported during the year. For employed women, we retain as working time the average of the usual working hours reported in March 1997 and March 1998 in the Labor Force Survey 6 .

\footnotetext{
${ }^{6}$ Child care expenditures contained in the tax returns refer to the whole 1997 year.
} 
The empirical distribution of the hours worked by working women has three peaks (Figure 1), roughly corresponding to half-time work, $80 \%$ part-time, and full time. Subsequently, we build four categories of working time, $[0,15]] 15,25]] 25,34$,$] , and more than 34$, referred to hereafter as $0,20,30,39$.

An important methodological choice relates to the measurement of the women's wage. We compute it indirectly from the tax files information, as the ratio of the salary income declared in the tax return to the number of working hours calculated from the Labor Force Survey because this method ensures consistency of wage incomes with child care expenditures, since both quantities come from the same source. In contrast, measuring hourly wages from the Labor Force Survey has the advantage of being less subject to measurement errors, but destroys the consistency between wage income and child care expenditures. As our modeling strategy relies heavily on the use of the household's budget constraint, we choose to use the tax files information.

Figure 1 : Distribution of Weekly Hours for Employed Women

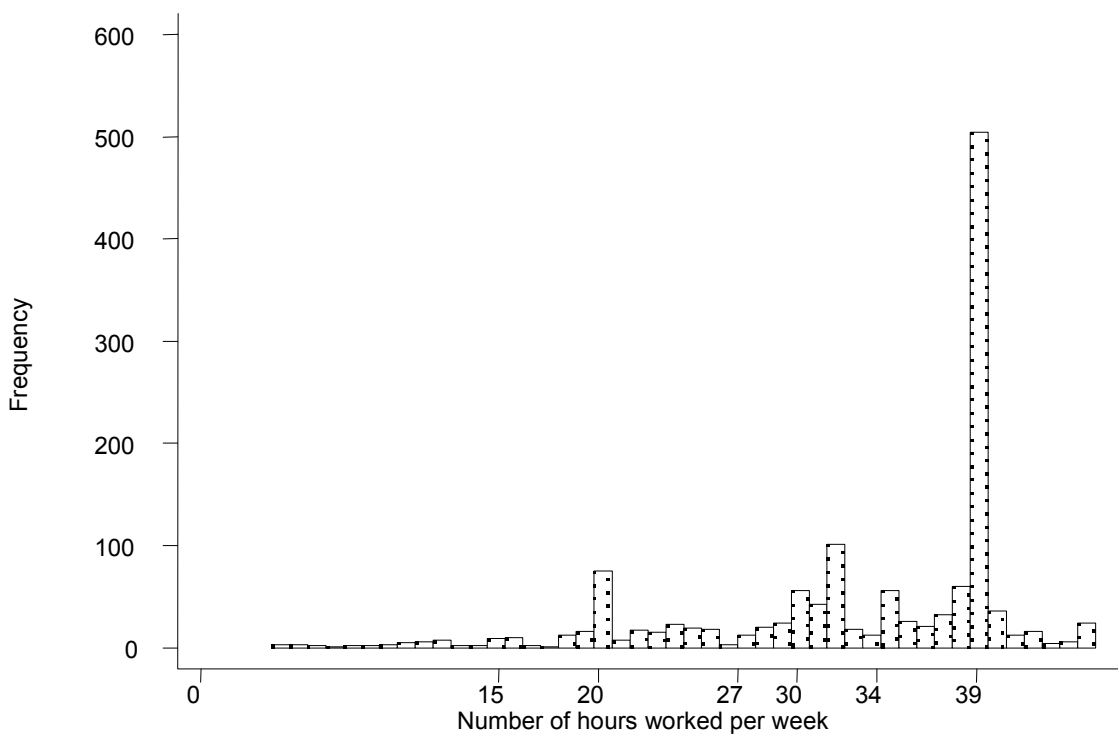

Source: Insee and Fiscal Services 1997 Labor-Force-tax Return matched survey

\subsection{Some descriptive analysis}

$25 \%$ of the households used formal paid child care in 1997. This proportion is higher for households with children under 3 (29\%). The choice of paid child care arrangements is strongly correlated to the women's status on the labor market. $46 \%$ of the households in which the woman works (respectively $60 \%$ of the households with children under 3 ) use paid child care, versus $4 \%$ only when the woman does not work. The proportion of women using paid child care increases with the working time of the mother.

The absence of declared child care expenditures on the tax return in a given year does not mean that the household does not use any paid child care arrangement: $15 \%$ of the households having children under 3 years old resort exclusively to unpaid care arrangements (Flipo and Sédillot, 2000) and some households may use informal paid child care. This observability issue will be dealt with in section 4 . 
Among households who use formal paid child care, the average per year net expenditure (after subsidy but before any tax cut) is about 1,100 euros (1,400 euros for households with children under 3 and 700 euros for households with only children aged 3 to 6). It increases with increasing working hours and on average the tax credit represents $16 \%$ of declared expenditures. Nearly $60 \%$ of the households report less than 1,000 euros per year (after subsidy but before any tax cut expenditures). This figure reaches $75 \%$ for households having only children from 3 to 6 years old. These relatively low expenditures reflect the high level of schooling among children aged 3 to 6 . Use of paid care arrangements in this case is likely to correspond to temporary accommodation of the children before or after school hours. $52 \%$ of the women in our sample did not work during the year 1997 (Table 2). This proportion is higher among low-skilled women: $60 \%$ for women who did not complete high school, $34 \%$ for women having a diploma equal to or higher than Bac +2 . Graduate women also more often work part-time.

Table 2 : Female Working Time and Paid Care Use (In \%)

\begin{tabular}{|c|c|c|}
\hline & $\begin{array}{l}\text { Households with } \\
\text { children under } 7\end{array}$ & $\begin{array}{l}\text { Households with } \\
\text { children under } 3\end{array}$ \\
\hline \multicolumn{3}{|l|}{ No paid care } \\
\hline $\begin{array}{l}\text { Non-working } \\
\text { women }\end{array}$ & 49.9 & 53.5 \\
\hline Half-time workers & 5.9 & 4.3 \\
\hline $\begin{array}{l}80 \% \text { part-time } \\
\text { workers }\end{array}$ & 5.2 & 3.4 \\
\hline Full-time workers & 14.7 & 9.9 \\
\hline All & 75.7 & 71.1 \\
\hline \multicolumn{3}{|c|}{ Paid care utilization } \\
\hline $\begin{array}{l}\text { Non-working } \\
\text { women }\end{array}$ & 2.0 & 2.7 \\
\hline Half-time workers & 2.0 & 1.9 \\
\hline $\begin{array}{l}80 \% \text { part-time } \\
\text { workers }\end{array}$ & 5.0 & 6.2 \\
\hline Full-time workers & 15.3 & 18.1 \\
\hline All & 24.3 & 28.9 \\
\hline All & 100.0 & 100.0 \\
\hline
\end{tabular}

Source: Insee and Fiscal Services 1997 Labor-Force-tax Return matched survey
Figure 2 : Female Hourly Wages in 1997, by Working Time

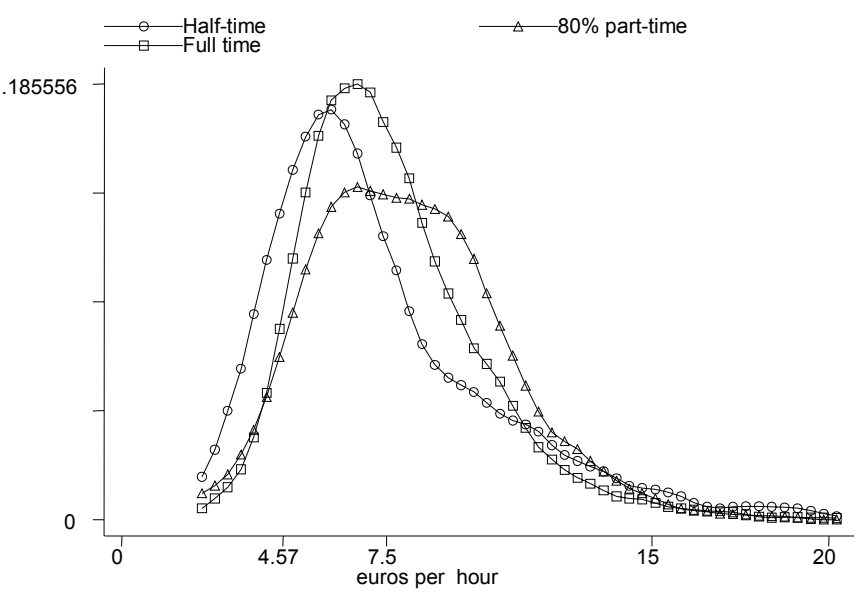

4.57 euros corresponds to the value of the hourly minimum wage in France in 1997.

The mean hourly wages vary between working hours brackets (figure 2). On average, part-time women working more than one half-time receive 8.1 euros per hour of work, versus 7.7 euros per hour for full-time women and 7.4 euros per hour for women working half-time. This can reflect selection of women with different characteristics into different classes of hours ${ }^{7}$ Figure 2 also clearly shows that the dispersion of hourly wages is higher for part-time workers than for full-time workers. The value 4,57 on the x-axis represents the hourly Smic in Euros. For a small proportion of women (about 5\%), the computed hourly wage is lower than the Smic. As indicated above, these women are deleted from our final sample.

\footnotetext{
${ }^{7}$ It might also reflect differing uses of part-time jobs between sectors.
} 


\section{Provisions related to child care in the French tax and benefit system}

This section is devoted to the presentation of the French tax and welfare systems, in relation to the subsidy of child care costs and the incentives for mothers of young children to reduce their labor supply. The first subsection presents the main provisions of the system in 1997. The second subsection discusses the precise modeling of the budget constraint of the households, which is the most important feature of our model.

\subsection{Fiscal and welfare provisions related to child care}

We focus on formal paid care outside the parental home (section 2). Child care expenditures outside home (net of subsidies) directly reduce the tax liability of households, provided the parents work at least half-time. The corresponding nonrefundable tax credit (which we will call CCTC hereafter, by analogy with the U.S. CDCTC) is worth $25 \%$ of the annual child care expenditures, within the limit of 2287 euros per child. The maximum annual tax cut is thus 572 euros per child between 0 and 6 years old.

In the French context, the two main collective care arrangements used are daycare centers and care by childminders outside parents' home (childminders in their home). Care in day-care centers is best described as a rationed good. Rationing is in general solved for by not admitted children if the mother does not work and by firstly serving women who work full-time, the others being supposed to be able to resort more easily to other child care arrangements. Households having a child admitted in a day-care center pay according to a scale that decreases with the size of the family and increases with its income, and varies from a municipality to another. For households at the top of the scale, the expenditure per child in a day-care center represents only about half the real cost of the care (Leprince, 2003). The difference between the operating costs of day-care centers and the sums paid by the households using them is financed in part by the state, in part by local jurisdictions and in part by the municipalities in which they are located.

In contrast, there seems to be a (highly subsidized) market for care by childminders in their home. Households with children under 7 years old ${ }^{6}$ resorting to a childminder may benefit from the Afeama (Assistance to Families for the Employment of Childminders in their home). This subsidy consists of the total reimbursement of social contributions on the childminder's wages to the household, plus a monthly allowance ${ }^{2}$.

Parents who stop working or work part-time after the birth of their second (or more) child may benefit from the APE (Parental Allowance for Education). Eligibility conditions include having worked more than 2 years during the 5 years (respectively 10 years) preceding the birth of the second (respectively third) child. APE consists in an allowance given until the child reaches the age of 3. The amount of the allowance takes different values depending on working time (complete stop of work, half-time jobs, $50 \%$ to $80 \%$ part-time jobs). The monthly amounts are respectively approximately 460,305 and 230 euros. Only $1 \%$ of the 0.5 recipients are men.

\footnotetext{
8 As school is mandatory for children aged 6 or more, most of the benefits and subsidies related to children incorporate this age as an eligibility condition.

${ }^{9}$ The amount of the allowance depends on the age of the child and, since January 2001, from the resources of the household. In July 1997, the monthly amount of the subsidy was 124 euros per child less than 3 years old, and 62 euros per child from 3 to 6 years old. About 0.4 million households benefit from this subsidy.
} 
These three subsidies represent a significant budgetary cost for the state: 1.2 billion euros for the Afeama, 0.15 billion euros for the CCTC, and 2.5 billion euros for the APE, for the year 1997 which is the relevant one for our study.

\subsection{The households' budget constraint}

As the whole French tax and benefit system is very complex, we model only the provisions which are most likely to influence the households' decisions of labor supply and child care (see Laroque and Salanié, 2002, for a complete description of the tax and benefit system and the related incentives). These include the whole income tax schedule, the minimum income programme (RMI), which consists in granting the difference between minimum income thresholds (depending on family structures) and total household resources if they don't reach this minimum, family benefits (not means-tested ones granted to family with at least 2 children and means-tested ones, such as the allowance for young children -APJE-) and the APE.

We do not take into account housing benefits, property taxes, unemployment benefits, and social contributions on wages. The reason for not modeling the first three items is that we lack relevant information in our dataset. Property taxes are unlikely to play a major role in the issues we examine here. Neglecting the other two items deserves some discussion. Unemployment benefits schedules depend on the past history of work (past wages, past hours of work, tenure), which are not known in our data. They decrease overtime, falling to zero after at most 2 years after the end of the last employment spell. However, in the static setting considered here, unemployment benefits could influence the choices of work of women ${ }^{10}$ Neglecting them is likely to result in undervaluing the non-working states, resulting in biased estimation of preferences for leisure.

Neglecting housing benefits may be the most prejudicial shortcoming in our context. Indeed, housing benefits depend negatively on the household's total income. Thus, they contribute to raise the marginal tax rate on labor income.

Finally, the choice not to model social contributions on wages is dictated both by the concern of avoiding to make the model more complex, and by the fact that taking them into account would not allow us to estimate the macroeconomic cost of policy reforms. This is because computing the cost of a particular reform would imply assessing the changes in the subsidies received by households. Those subsidies vary with the child care arrangements chosen, and any policy reform will cause changes in the choices of arrangements. Since our data do not allow us to model this choice, the component of the cost of a reform due to changes in the relative use of different care arrangements cannot be computed.

To sum up, the resources taken into account in this paper are net wages $\frac{11}{11}$, and net child care expenditures (i.e. after-subsidy, but before-tax).

To illustrate some relevant features of the tax and benefit system, we consider some stylized cases of couples, differing by the number of children, the husband's annual income, the hourly wage of the wife, and the household's monthly child care expenditures. In each case, for the four different options of female working time, Table 3 gives the net resources, the incidence of RMI, the amount of APE, and the CCTC tax cut. We do not illustrate the budget constraints using traditional curves, as the choice of working hours is not continuous here.

\footnotetext{
10 The unemployment benefits of men are accounted for in our framework, since the total resources of men are taken to be exogenous, see below.

${ }^{11}$ Income as declared by the households in their tax returns is very close to net wage.
} 


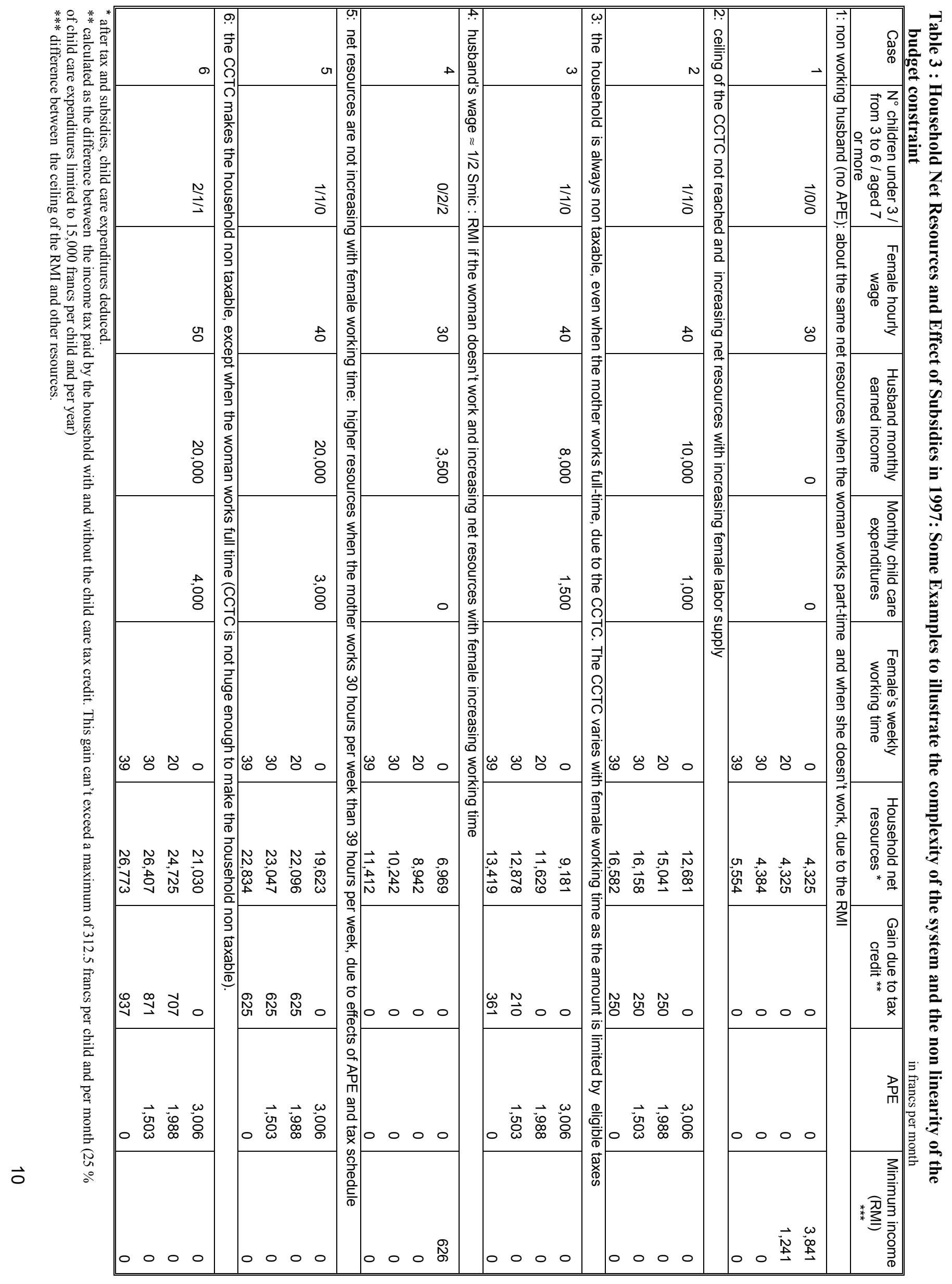


In the population we study, the RMI does not play a very significant role. Indeed, $95 \%$ of the sample men are employees (the 5\% remainders are unemployed) and $48 \%$ of the households are eligible for the APE. Very often, the sum of the husband's wage and the family benefits exceed the ceiling of the RMI. In case 1, the household is not eligible for the APE and gets the RMI when the woman works part-time. In case 4, the annual wage of the husband approximately corresponds to half of the Smic (legal minimum wage) and the household benefits from RMI when the woman does not work. The other cases illustrate the various effects of the CCTC. CCTC cannot decrease with increasing working time of the mother, but can reach the ceiling rather quickly. In case 2 , the tax cut is equal to $25 \%$ of child care expenditures. In case 5 , annual child care expenditures exceed 2287 euros per child. In case 3, the ceiling is never reached and the CCTC makes the household nontaxable even when the mother works full-time. In case 6, the husband's income is higher and the tax cut is not sufficiently large to make the household nontaxable when the woman works full-time. In certain cases, the net resources of the household may not increase with the working hours of the woman. For example in case 5, the resources are higher at 30 hours than at 39 hours, because the loss of the APE and the increase of taxes more than compensate the increase in woman's labor income.

\section{The model}

As mentioned above, our data contain the same information on child care as those used by Ribar (1995), i.e., formal child care expenditures. Nothing is known of the precise care arrangement used, or of informal care expenditures. Moreover, we cannot break down care expenditures into quantities (hours of care) and prices (unit prices of care hours). Thus, it is not possible to estimate a marshallian demand function for hours of care. We have to make an identifying assumption as regards the demand for formal care. Although our theoretical model appears to differ from Ribar's one, it leads to an econometric specification very similar to his.

\subsection{The theoretical framework}

The labor supply of the man is taken to be exogenous, as the adjustments of working time mostly concern women. The woman can choose to work or not, as well as hours of work when she works. The household can use formal paid care arrangements or alternative arrangements, including care by the mother, another person, or informal paid care.

Preferences of the family depend on the consumption $\mathrm{c}$ of a composite good taken as the numéraire and on the leisure time of the woman, $L=T-h$ where $h$ is the woman's number of hours worked.

We make two simplifying assumptions due to the lack of data on child care hours. We first assume that the family needs a certain amount of child care hours $Q$, which is exogenous and depends only on the family structure. This quantity of child care is produced by two inputs, the leisure time of the mother, $L$, and formal hours of care, $G$. The family has to produce a certain amount of care:

$$
Q(L, G, X)=\bar{Q}
$$

where $X$ is a vector of exogenous variables, which affect the easiness to use informal care arrangements, such as the proximity of parents or relatives.

Conditional on the mother's hours of work, the relation 1 can be written:

$$
G=g(L, \bar{Q}, X)
$$


The household optimizes the following system:

$$
\left\{\begin{array}{cl}
\max _{C, L} & U(L, C) \\
\text { s.c. } & C=w H+N-d(G)-T(w H, N, d(G)) \\
& G=g(L, \bar{Q}, X) \\
& H \geq 0, G \geq 0
\end{array}\right.
$$

where $\mathrm{w}$ denotes the hourly wage of the woman, $\mathrm{N}$ denotes exogenous income, including wage income of the husband, $d(\mathrm{G})$ denotes formal child care expenditure and $\mathrm{T}$ is the tax paid net of social transfers. Note that $\mathrm{T}$ depends on formal care expenditures because of the CCTC.

At this stage, we introduce a change in the model, in order to account for informal care expenditures, which are not observed. Informal care expenditures affect the budget constraint both directly and indirectly, because using informal care may have costs in time or in kind to the household. We account for this by letting $F=1 \mathrm{G}>0$, the dummy variable which takes the value 1 if the chosen care arrangement is formal, 0 otherwise, enter the utility function, which becomes $\mathrm{U}(\mathrm{C}, \mathrm{L}, \mathrm{F})$. This technique is also used by Ribar $(1995)^{12}$.

\subsection{Econometric specification}

We specify a quadratic form for the utility function.

$$
\widetilde{U}(c, h, f)=c+\beta_{h} h+\beta_{f} f+\beta_{c c} c^{2}+\beta_{c h} c h+\beta_{h h} h^{2}+\beta_{f h} f h
$$

Unobserved heterogeneity is introduced both in the coefficients of the preference function and in the wage and child care expenditure equations. Coefficients $\beta_{h}$ and $\beta_{f}$ are random:

$$
\begin{aligned}
& \beta_{h}=x_{h} \gamma_{h}+\varepsilon_{h} \\
& \beta_{f}=x_{f} \gamma_{f}+\varepsilon_{f}
\end{aligned}
$$

The coefficients $\beta_{c c}, \beta_{c h}, \beta_{h h}, \beta_{f h}$ depend only on observed characteristics of the households.

The inclusion of a cross effect $f . h$ in the utility function aims at reflecting possibly different attractiveness of formal paid care arrangements depending on the working time of the mother. Indeed, the supply of care services is not completely flexible with respect to the mother's schedule of work. The $f . h$ term can also help to control for effects, which are not strictly related to the households' preferences. In particular, sometimes the choice of care modes can be conditional on the situation of the mother on the labor market because of rationing issues (see section 3.1). This concern leads us to adopt an even more flexible specification, which consists in including three different terms 20.f. $\beta_{f 20}, 30 . f . \beta_{f 30}, 39 . f . \beta_{f 39}$ in the utility function in place of $\beta_{f h} f h$. The explanatory regressors are the same for the three coefficients: a constant and the number of children under 3 when the model is estimated on the sample of households with children under the age of 7.

\footnotetext{
12 An alternative choice would be to proceed like Heckman (1974) and model formal and informal care prices as functions of observed and unobserved characteristics of the household.
} 
Unobserved heterogeneity also concerns wages and child care expenditures. The hourly wage and the child care expenditure equations write:

$$
\begin{aligned}
& \ln w=x_{w} \gamma_{w}+\varepsilon_{w} \\
& \ln d=x_{d} \gamma_{d}+\varepsilon_{d}
\end{aligned}
$$

Hours of work intervene as regressors in the expenditure equation. The relation between hours worked and child care expenditure is very flexible (in particular it is not necessarily linear). In contrast, for the sake of simplicity, we choose not to include working hours as regressors in the wage equation (for this modeling choice, see for example Laroque and Salanié, 2000) nor in the variance of $\sigma_{w}$.

The four residuals of the model are supposed jointly normal, with mean 0 and covariance matrix $\Sigma$. We do not impose any constraint on $\Sigma$, other than symmetry and positivity ${ }^{13}$.

The model is identified by the normalization of the coefficient of $\mathrm{c}$ in the utility function and by multiple non-linearities in the budget constraint. In addition, we make several exclusion restriction assumptions.

Estimating the model requires taking account of the nonconvexity of the households' budget constraint, which results from the complexity of the tax-benefit system. There are 8 possible states, which result from the combination of the four choices for working hours (see section 2) with the dummy for using formal paid care. As in Keane and Moffitt (1998), the estimation relies then on the direct comparison of the household's utility levels in the eight situations. An important exception concerns women whose estimated productivity is lower than the hourly Smic. We suppose that these women cannot work. Their choice is thus limited to the decision to use formal paid care or not while not working (see Appendix B for details).

\subsection{Labor demand and child care supply constraints}

Our model supposes that participation and hours can be freely chosen, which may seem too strong an assumption. In our sample, a huge majority of the women who did not work during the year 1997 declare themselves as housewives, and not searching for a job. However, the share of mothers who do not work is definitely higher among the less educated women, which may be an indication that non-participation could be constrained. However, our model incorporates the (arguably) most important constraint on labor supply, in the form of the minimum wage. Having a productivity lower than the minimum wage (Smic) hinders women from working. As this truncation effect is expected to bear mostly on low-qualified women, one can think that a good share of the constraints on labor supply is taken into account. Other factors could of course play a role. To reflect the idea that a high local rate of unemployment can dissuade some women to search for a job, we introduce the local unemployment rate among the regressors of the preferences for work coefficient $\beta_{h}{ }^{4}$.

\footnotetext{
${ }^{13}$ We use the parameterization $\Sigma=\mathrm{CC}^{\prime}$, where $\mathrm{C}$ is triangular, and do not impose any constraint on the coefficients of the Choleski matrix C.

${ }^{14}$ The unemployment rate is calculated at the Departement area level. There are 95 Departements in France.
} 
Concerning the choice of working hours when the woman works, it is difficult to know if the observed choices are constrained by the local demand for part-time jobs ${ }^{15}$. However, according to the Labor Force Survey, the share of women working part-time who declare they would be willing to work more is definitely lower among young mothers $(25 \%)$ than among the whole female population (33\%). A frequently used means of taking these constraints into account is to introduce exogenous probabilities of success in finding a job of a certain type, conditional on wanting a job of that type (Choné, 2002). Given the already complex nature of the model, we do not follow this way. Also, not taking constraints on hours into account may be less unrealistic in our context of discrete choice of working hours (four brackets) than in a context of continuous distribution for supplied hours.

Supply constraints on the care market may concern the local provision of care services (existence of day-care centers, of alternative formal care arrangements in the community of residence of the family), or the existence of alternative care arrangements (e.g. having relatives nearby). We have no direct information on this point. We take this fact into account in the specification of the preferences. We also introduce two explanatory variables. The first one is an indicator summarizing the supply-side situation as regards child care ${ }^{16}$. It is included in both the regressors of the preference for paid child care $\beta_{f}$ and the regressors of the care expenditures equation. The other one is a dummy variable indicating whether the couple lives in the department of birth of one of its two members. It is introduced in the expenditure equation, to mitigate the absence of direct information on the spatial proximity of parents and relatives who could take care of the children.

\subsection{Structure of the model and likelihood}

The majority of studies proceed in several stages, initially estimating wage and expenditure equations, then in a second stage the coefficients of the discrete-choice model. This kind of method generates consistency problems between the first stage reduced-form equations and the decision model estimated in the second stage, as the equations estimated in the first stage are not the true reduced-form of the complete model. A contribution of this work is the simultaneous estimation of all equations, which in particular allows us to take into account correlations between unobserved tastes and the residuals of the wage and expenditure equations. The model is estimated by simulated maximum likelihood using GHK-type methods (Appendix A).

The likelihood contributions differ according to whether the woman works or not and uses paid child care or not. According to the case, we observe the wage and expenditures, one of those quantities only, or none of them. Moreover, calculation is further complicated by the inclusion of a minimum wage. The contributions of the observations to the likelihood in the various cases are presented in Appendix B.

Once estimated the parameters of the model, simulations of policy reforms can be implemented. We draw residuals and simulate the endogenous variables of the model (wages, expenditure, levels of utility, and finally the states before and after the reform). This method allows one to construct matrices of transition between states caused by the reform in order to

\footnotetext{
${ }^{15}$ Part-time jobs are more frequent in the service sector than in industry sector. Part-time jobs could also be more costly to firms, because of the tax system. See Del Boca (2002) for a discussion of the Italian case on this topic.

${ }^{16}$ This variable is constructed as follows: we first add the capacities in day-care centers and the number of children kept by childminders, at the Departement level. Then we divide this number by the number of children aged 1, 2 or 3 in the same area.
} 
analyze switches between states due to the reform and to estimate mean elasticities computed as the ratios of the relative changes in the dependent variables to the change in the appropriate parameter of the model. To analyze changes in working hours due to the reforms, it is useful to decompose changes in the total amount of hours worked between an extensive effect, which is here due to switches between participation and non participation, and an intensive effect, which is here the change in the total amount of working hours for women who work before and after the reform.

\section{Results}

The model is estimated on two fields: the complete sample of families with children less than 7 years old (2655 observations) and the subsample of families with at least one child under 3 (1296 observations). Indeed, we expect to find higher elasticities of participation and paid care use for families with young children, given that child care expenditures are higher for them. This estimation on two different subsamples is also a means of assessing the robustness of the results, by comparing the figures resulting from the two models on their common field of families with children under 3. For all the specifications we use, the results from the two models are very close, both in terms of transitions between states and as regards estimated elasticities. Our results thus seem relatively robust. Therefore we only present and discuss results from the model estimated on the full sample (Table 4).

\subsection{Coefficient estimates}

As usual in female labor supply analysis, the hourly wages increase with educational level and professional experience, and are higher in the Paris area than in the province (Table 4). The child care expenditure equation is trickier to implement in a satisfactory way ${ }^{17}$. Despite numerous alternative specifications, we were not able to reduce the standard deviation of the expenditure residual significantly. The point estimate for this standard error is 1.34 , which reflects the great variability of the households' care expenditures, even after controlling for observed characteristics. It is quite difficult to analyze directly the coefficients of the expenditure equation because working hours are included as regressors and because of correlations between unobserved heterogeneity terms in the expenditure equation and preference for paid child care and hours of work. The negative values for the working hours may seem inadequate. We have checked that, conditional on the use of paid child care and working hours, child care expenditures increase with increasing working time. Two exogenous parameters have the expected sign: child care expenditures decrease with increasing child care supply and are higher in Paris.

Turning to the preference coefficients, utility is concave in consumption and hours of work. In particular, the marginal utility of income is decreasing. The aversion for work at zero hours of work (equal to $-\beta_{h}$ see equation (3)), increases with the number of children, but decreases with age. It is higher for foreigners, and for women living in areas where the unemployment rate is high. Lastly, when the husband works over 45 hours a week, the wife wants to work less. The coefficient for the preference to formal paid care $\beta_{f}$ is higher when the

\footnotetext{
17 The fact that this equation is difficult to estimate is common. Guillot (1996) finds a $\mathrm{R}^{2}$ of only 0.097 for his expenditure equation. The $\mathrm{R}_{2}$ we found in preliminary regressions and Tobit regressions were also very low, around 0.10 .
} 
0
0
0
0
0
0
0
0
0
0
0
$\Xi$
0
0
0
0
0
0
0
0
0
0
3
0
0
0
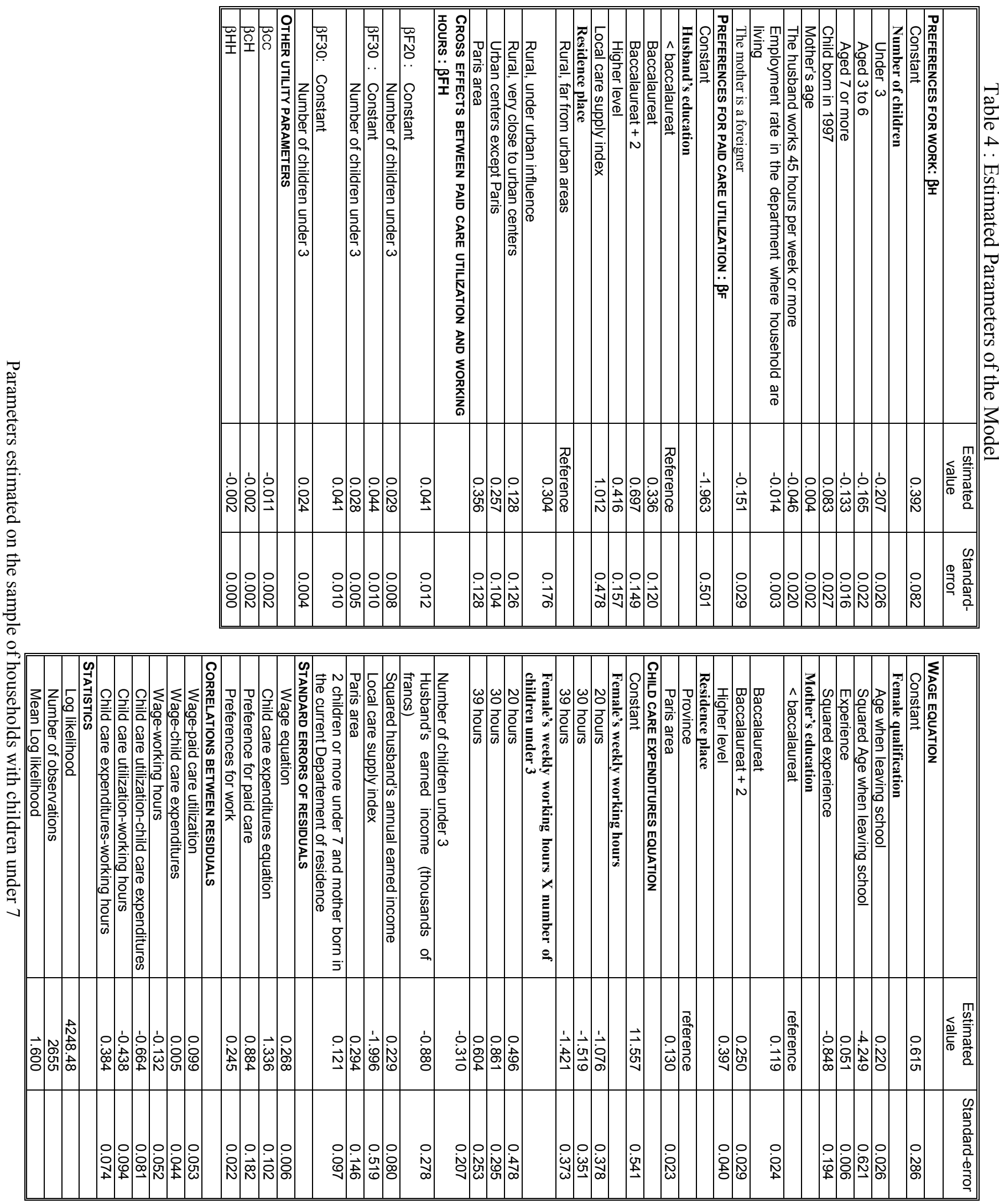
husband is high educated and when the household lives in urban areas. It increases with local child care supply. But the standard error for unobserved heterogeneity is high, which may partly stems for a lack of data on the specific care arrangement chosen and hours of child care.

The three coefficients $\beta_{f h}$ are all positive and increasing with the number of children under 3. In the field of households with children of less than 7 years, a Wald test and a likelihood ratio test lead to reject the equality of the coefficients $\gamma_{f 20}, \gamma_{f 30}, \gamma_{f 39}$ at the $10 \%$ level.

On the six correlations between the residuals of the model, only two appear not significant (the correlations between the wages and the expenditure residuals, and between the wages and the preferences for the use of paid child care). The correlation between the residuals of the expenditure equation and of the preferences for the use of paid child care is strongly negative, which conforms to intuition (households increase their use of paid care if expenditures are lower) ${ }^{118}$.

The model reproduces the observed situations relatively well. The fit of the discrete probabilities (Table 5) is satisfactory and the predicted frequencies for each state remain close to those actually observed when we break the sample down by age of the children and education level of the mothers.

Table 5: Fit of the Model estimated on the Full Sample

\begin{tabular}{|c|c|c|c|c|c|}
\hline & $\begin{array}{l}\text { Paid care } \\
\text { utilization }\end{array}$ & $\begin{array}{c}\text { Female } \\
\text { participation } \\
\text { rate }\end{array}$ & $\begin{array}{l}\text { Women } \\
\text { working half- } \\
\text { time }\end{array}$ & $\begin{array}{l}\text { Women working } \\
80 \% \text { part-time }\end{array}$ & $\begin{array}{l}\text { Women } \\
\text { working full- } \\
\text { time }\end{array}$ \\
\hline \multicolumn{6}{|c|}{ All households with children under 7} \\
\hline Observed & 23.6 & 45.8 & 7.0 & 10.0 & 28.7 \\
\hline Simulated & 24.2 & 46.7 & 8.9 & 8.9 & 28.9 \\
\hline \multicolumn{6}{|c|}{ Households with children under 3} \\
\hline Observed & 27.2 & 40.1 & 5.6 & 7.8 & 25.9 \\
\hline Simulated & 27.4 & 41.6 & 7.5 & 9.3 & 24.8 \\
\hline
\end{tabular}

\subsection{Elasticities of participation and paid care use}

All the elasticities are gathered in Table 6.

We firstly uniformly increase the hourly wages of women by $10 \%$. Female employment then increases strongly by +3.8 points (Table 7 ). Both full-time and part-time work increase strongly. Reduction of supplied hours in response to a wage increase is very rare in the sample. The total number of hours worked increases by $10.5 \%$, of which a third is due to an increase in supplied hours of women who worked before the reform, and two thirds is due to greater participation. This rise of employment coincides with a rise in the use of paid child care: +1.7 points $(2.1$ points for the families with children under 3).

\footnotetext{
18 The estimated values of the correlations are robust to all alternative specifications and estimations on different fields. That shows that a priori assumptions one could make about the correlation structure in such a model are not well founded. Also, the fact that correlations between preferences on one hand, wages and expenditures on the other hand, are not zero justifies the need for joint estimation of all the equations of the model.
} 
The corresponding elasticity of female participation is 0.80 ( 0.91 for families with children of less than 3 years old) (see table 6). The wage elasticity of paid care use amounts to 0.70 . This last elasticity is higher than those usually found in American data. This result is due to the way one takes into account the censorship of the minimum wage. Indeed, if we also increase the Smic by $10 \%$, the two elasticities are divided by about two. In this case, the women whose estimated productivity is below the Smic are the same before and after the reform: the wage increase does not have any impact on the choices of these women, since they cannot find a job in both cases.

Table 6 : Uncompensated Elasticities and Effects of the Minimum Wage

\begin{tabular}{|c|c|c|}
\hline & $\begin{array}{l}\text { Households with } \\
\text { children under } 7\end{array}$ & Households with children under 3 \\
\hline \multicolumn{3}{|c|}{ Elasticity of paid care utilization } \\
\hline Care expenditure & -.29 & -.31 \\
\hline Wage * & .70 & .77 \\
\hline $\begin{array}{l}\text { Wage, minimum wage } \\
\text { increased }{ }^{* *}\end{array}$ & .33 & .35 \\
\hline Income & -.02 & -.00 \\
\hline \multicolumn{3}{|c|}{ Elasticity of female participation } \\
\hline Care expenditure & -.01 & -.01 \\
\hline Wage * & .80 & .91 \\
\hline $\begin{array}{l}\text { Wage, minimum wage } \\
\text { increased }{ }^{* *}\end{array}$ & .30 & .33 \\
\hline Income & -.18 & -.18 \\
\hline \multicolumn{3}{|l|}{ Elasticity of worked hours } \\
\hline Care expenditure & -.01 & -.02 \\
\hline Wage * & 1.05 & 1.20 \\
\hline $\begin{array}{l}\text { Wage, minimum wage } \\
\text { increased }^{* *}\end{array}$ & .26 & .29 \\
\hline Income & -.19 & -.19 \\
\hline Number of observations & 2655 & 1296 \\
\hline
\end{tabular}

* : All female wages increased by $10 \%$, no change in the minimum wage.

** : All female wages increased by $10 \%$, minimum wage increased by $10 \%$.

To obtain income elasticities, we simulate a uniform increase of men's wages by $10 \%$. The corresponding transition matrix (not shown) indicates that the overall effect is a fall in female labor supply. But the effects differ following the initial labor supply of women. Whereas $9 \%$ of the women working 20 hours in the benchmark case would stop to work, hardly any woman working 30 hours in the benchmark case would stop participating. Instead, those women tend to reduce their hours supply to 20 hours $(7 \%$ of them). A few women working full-time would reduce their working hours to 30 hours, but again hardly any would choose not to work. Overall, the implied elasticities of participation and hours worked are respectively -.18 and -.19. The former figure is in the range of previous estimates in other countries (see Blundell and MaCurdy, 1999). It is a little higher in absolute value than the estimate in Laroque and Salanié (2002), who study the labor supply of French women but do not consider child care. Paid care utilization would slightly decrease by .1 point. In fact, two opposite effects are at work here. On one hand, since women tend to reduce their labor supply, fewer of them need to use paid care. On the other hand, the income rise has a positive effect on the demand for paid child care. Overall, these two effects cancel out, in spite of the non negligible reduction of female labor supply. 
Since our data do not allow us to break down child care expenditures into price and quantities, we cannot calculate true elasticities of the demand for child care. We measure the sensitivity of labor supply and child care use by simulating an exogenous $10 \%$ increase in child care expenditures. As table 7 shows, the impact on the overall participation rate of women is small ( -0.04 point). The change is a little stronger for mothers of children under 3 . Adjustments of working time are also small in magnitude. Half-time employment increases slightly, whereas

Table 7: Employment and Care Utilization Effects of Simulated Policy Changes

(Differences between the probabilities before and after the change)

\begin{tabular}{|c|c|c|c|c|c|}
\hline Policy Change & $\begin{array}{l}\text { Paid care } \\
\text { utilization }\end{array}$ & $\begin{array}{c}\text { Female } \\
\text { employment }\end{array}$ & $\begin{array}{c}\text { Half-time } \\
\text { employment }\end{array}$ & $\begin{array}{c}80 \% \text { part-time } \\
\text { employment }\end{array}$ & $\begin{array}{c}\text { Full-time } \\
\text { employment }\end{array}$ \\
\hline \multicolumn{6}{|l|}{ All households with children under 7} \\
\hline $\begin{array}{l}\text { Increase female hourly wages by } \\
10 \% \text {, no change in the minimum } \\
\text { wage }\end{array}$ & 1.7 & 3.8 & 0.9 & 0.8 & 2.1 \\
\hline $\begin{array}{l}\text { Increase female hourly wages and } \\
\text { minimum wage by } 10 \%\end{array}$ & 0.8 & 1.4 & 0.5 & 0.4 & 0.5 \\
\hline $\begin{array}{l}\text { Increase child care expenditures } \\
\text { by } 10 \%\end{array}$ & -0.7 & 0.0 & 0.0 & 0.0 & 0.0 \\
\hline Eliminate tax credit & -1.3 & -0.1 & 0.1 & -0.1 & -0.1 \\
\hline Double care expenditures & -5.5 & -0.3 & 0.3 & -0.2 & -0.4 \\
\hline Eliminate all the Ape program & 1.4 & 2.5 & 0.7 & -1.1 & 2.9 \\
\hline $\begin{array}{l}\text { Eliminate the Ape for the second } \\
\text { child only }\end{array}$ & 1.1 & 1.8 & 0.4 & -1.0 & 2.3 \\
\hline $\begin{array}{l}\text { Eliminate the Ape for part-time } \\
\text { women only }\end{array}$ & 0.0 & -2.2 & -3.3 & -1.8 & 2.9 \\
\hline $\begin{array}{l}\text { Extend the APE to women with } \\
\text { only one child }\end{array}$ & -0.6 & -0.8 & -0.1 & 1.0 & -1.6 \\
\hline \multicolumn{6}{|l|}{ Households with children under 3} \\
\hline $\begin{array}{l}\text { Increase female hourly wages by } \\
10 \% \text {, no change in the minimum } \\
\text { wage }\end{array}$ & 2.1 & 3.8 & 0.9 & 0.9 & 2.1 \\
\hline $\begin{array}{l}\text { Increase female hourly wages and } \\
\text { minimum wage by } 10 \%\end{array}$ & 0.9 & 1.4 & 0.5 & 0.4 & 0.5 \\
\hline $\begin{array}{l}\text { Increase child care expenditures } \\
\text { by } 10 \%\end{array}$ & -0.8 & -0.1 & 0.1 & -0.1 & 0.0 \\
\hline Eliminate tax credit & -1.4 & -0.1 & 0.2 & -0.1 & -0.1 \\
\hline Double care expenditures & -6.5 & -0.4 & 0.5 & -0.5 & -0.5 \\
\hline Eliminate all the Ape program & 2.4 & 4.0 & 1.1 & -1.7 & 4.5 \\
\hline $\begin{array}{l}\text { Eliminate the Ape for the second } \\
\text { child only }\end{array}$ & 1.8 & 2.8 & 0.7 & -1.4 & 3.5 \\
\hline $\begin{array}{l}\text { Eliminate the Ape for part-time } \\
\text { women only }\end{array}$ & -0.1 & -3.2 & -4.8 & -2.9 & 4.5 \\
\hline $\begin{array}{l}\text { Extend the APE to women with } \\
\text { only one child }\end{array}$ & -0.9 & -1.2 & -0.2 & 1.4 & -2.5 \\
\hline
\end{tabular}

the other choices of hours become less frequent. The corresponding elasticities of participation and working hours are practically zero. The effects on the use of formal paid child care are somewhat bigger. Formal paid care use decreases by 0.7 point, meaning an elasticity of -0.29 . Among the women who change their ( $h, f)$ combination after the reform, 57\% do not change their working time but cease to use paid care, and 34\% both decrease their working hours and stop 
using paid child care. Overall, the elasticities we find in this simulation exercise are a little lower than those given by Ribar (1995).

\section{Some policy simulations}

The programs designed to help families with young children are multiple and may be expected to have quite diverse effects on the labor supply of women and on the use of paid child care. While programs like the Afeama and the CCTC aim at reducing the cost of child care and perhaps allowing young mothers to continue to work, the APE was initially designed to encourage lowproductivity women to withdraw from the labor market. This study tries to assess the effects of each type of program on the female labor supply and the use of formal paid child care in France. The first simulation consists in modifying the schedule of the CCTC. The second consists in doubling the before-tax child care expenditures of the households. Lastly, we change the schedule of the APE. The size of the French CCTC is relatively modest compared to that of the APE. Thus, in the sequel we spend more time on the third set of results than on the first. Recall that due to the data available, the present study only examines paid care arrangements outside the parental home. In consequence, we cannot simulate reforms devoted to child care arrangement in parents' home, nor assess the impact of a change in the CCTC schedule in the use of care at home by the households.

\subsection{Modifying the CCTC schedule}

The CCTC results on average in a $16 \%$ cut in the expenditures of households using paid child care. Merely suppressing the CCTC would result in a weak reduction in total female participation (-0.1 point), women leaving the labor market stopping to use formal paid care. Women also tend to decrease their working hours in order to lower care expenditures. The fall in overall female participation breaks down into a rise of part-time employment and a greater fall for the others types of work (table 7). Paid care use decreases by 1.3 points. Another simulation consisting in increasing the subsidy rate of CCTC from $25 \%$ to $50 \%$ results in a slight increase in total female participation and a bigger increase in paid care use.

\subsection{Doubling child care expenditures}

Doubling before-tax child care expenditures is not economically meaningless in the French context, since a very significant share of child care expenditures is covered by subsidies. For instance, doubling the care expenditures of households using care by a childminder would approximately amount to dividing by two the amount of the Afeama, which would still leave an important part of the gross expenditure to the Welfare Bureau and the local communities.

Doubling the care expenditures magnifies the effects put into evidence above. Total female participation decreases by 0.3 point (table 7). The number of hours worked drops more strongly : $-2 \%$, of which $1 \%$ is due to women who stop working and $1 \%$ is due to changes of working hours of employed women. Using paid care decreases by 5.5 points. Average annual care expenditures for households who utilize formal paid care would raise to 1,820 euros after the reform, against 1,280 euros before the reform 19 .

\footnotetext{
${ }^{19}$ As usual in models with selection, this figure combines two effects. Faced with a rise in child care costs, households who still use paid care after the reform try to lower hours of child care (in our model, they may only do
} 


\subsection{Modifying the APE schedule}

The amount of the APE is higher, the less the parent work (see section 3.1). These financial incentives have a strong influence over the working hours of mothers of young children. The benefit is granted until the child reaches the age of 3 . Thus, in this subsection, we focus on families having children under 3.

According to the model, the suppression of APE would cause a rise of 4.5 points of fulltime work, a rise of 4 points of female participation, and an increase of 2.4 points of paid care use (see the transition matrix in table 8). The transitions on the labor market take the form of numerous shifts toward immediately higher hours brackets. Theses shifts results in a $11 \%$ rise of total worked hours, $44 \%$ of which comes from increases in hours from women who participated before the reform, and 56\% from women (re)entering the labor market.

We simulate the reverse natural experiment of the 1994 extension of the APE to parents of 2 children, by removing the APE for families with exactly two children including at least one under 3. The participation rate of the concerned women would jump from 44 to $50 \%$, and the number of worked hours would increase by $16 \%$ (tables 7 and 8 ). Thus, $11 \%$ of non participating women would take up a job. This figure is slightly lower but of the same order as that put forward by Piketty (1998). This comforts us in the robustness of our other findings.

The choice of working hours is very sensitive to financial incentives (tables 7 and 8 ). The suppression of the APE for women working $80 \%$ part-time would result in a strong decrease in this type of work. Only 3\% of the mothers of children under 3 would work $80 \%$ part-time after the reform versus $9 \%$ before the reform. Women in this hours bracket before the reform would switch equally to full-time or to half-time (the latter choice enabling them to benefit from halftime APE). Only few women would stop working, even though they may benefit from APE by doing so. The effect of the reform on the total working time of women would be weak, the effects of switching towards half-time and full-time compensating one another. If we remove APE granted for half-time while maintaining the other forms of APE, 50\% part-time work strongly decreases ( $2 \%$ of women versus $7 \%$ before the reform), two thirds of the concerned women switching to $80 \%$ and one third stopping to work. Female total employment would drop by 2 points, but the number of hours worked would remain stable. Finally, suppressing all the parttime APEs would result in both a lower participation rate and a rise in full-time work, because of numerous transfers of women currently working half-time to non-participation and women working $80 \%$ part-time towards full-time. Once again, these adjustments partly reflect differences in behavior between low-skilled, half-timer and high-skill, long part-timer women. These differences confirm the usefulness of distinguishing different hours brackets in the analysis.

so by switching to a lower hours bracket). At the same time, some "marginal" households, presumably the ones who had the smaller care expenditures before the reform, will stop using paid care. 
Table 8 : Transition Matrices

(h denotes the number of female working hours per week, f denote paid care utilization )

For households with children under the age of 3

a) Eliminate all the whole Ape program

Individuals in the row $(\mathrm{h}, \mathrm{f})$ change to states ...

\begin{tabular}{|c|c|c|c|c|c|c|c|c|c|}
\hline & $(0,0)$ & & $(30,0)$ & $(39,0)$ & $\overline{(0,1)}$ & $(20,1)$ & $(30,1)$ & $(39,1)$ & All \\
\hline$(0,0)$ & 92.9 & 4,4 & 0.0 & 0.0 & 0.0 & 2.0 & 0.7 & 0.0 & 100.0 \\
\hline$(20,0)$ & 1.0 & 66.0 & 21.0 & 0.0 & 0.0 & 0.0 & 6.9 & 5.0 & 100.0 \\
\hline$(30,0)$ & 0.1 & 0.1 & 40.1 & 45.8 & 0.0 & 0.0 & 0.0 & 13.8 & 100.0 \\
\hline$(39,0)$ & 0.0 & 0.0 & 0.0 & 100.0 & 0.0 & 0.0 & 0.0 & 0.0 & 100.0 \\
\hline$(0,1)$ & 2.3 & 0.0 & 0.0 & 0.0 & 92.8 & 4.9 & 0.0 & 0.0 & 100.0 \\
\hline$(20,1)$ & 0.3 & 0.1 & 0.0 & 0.0 & 0.1 & 66.3 & 33.1 & 0.1 & 100.0 \\
\hline$(30,1)$ & 0.2 & 0.0 & 0.0 & 0.0 & 0.0 & 0.1 & 62.0 & 37.7 & 100.0 \\
\hline$(39,1)$ & 0.0 & 0.0 & 0.0 & 0.0 & 0.0 & 0.0 & 0.0 & 100.0 & 100.0 \\
\hline
\end{tabular}

b) Eliminate only the Ape for $80 \%$ part-time women Individuals in the row $(\mathrm{h}, \mathrm{f})$ change to states ...

\begin{tabular}{||c|r|r|r|r|r|r|r|r|c||}
\hline \hline & \multicolumn{1}{|c}{$(0,0)$} & $(20,0)$ & $(30,0)$ & $(39,0)$ & \multicolumn{1}{c}{$(0,1)$} & \multicolumn{1}{c}{$(20,1)$} & $(30,1)$ & $(39,1)$ & All \\
\cline { 2 - 12 } & 100.0 & 0.0 & 0.0 & 0.0 & 0.0 & 0.0 & 0.0 & 0.0 & 100.0 \\
\hline$(20,0)$ & 0.0 & 100.0 & 0.0 & 0.0 & 0.0 & 0.0 & 0.0 & 0.0 & 100.0 \\
\hline$(30,0)$ & 0.0 & 40.0 & 18.0 & 34.0 & 0.0 & 0.0 & 0.0 & 8.0 & 100.0 \\
\hline$(39,0)$ & 0.0 & 0.0 & 0.0 & 100.0 & 0.0 & 0.0 & 0.0 & 0.0 & 100.0 \\
\hline$(0,1)$ & 0.0 & 0.0 & 0.0 & 0.0 & 100.0 & 0.0 & 0.0 & 0.0 & 100.0 \\
\hline$(20,1)$ & 0.0 & 0.0 & 0.0 & 0.0 & 0.0 & 100.0 & 0.0 & 0.0 & 100.0 \\
\hline$(30,1)$ & 0.2 & 10.9 & 0.0 & 0.0 & 0.0 & 23.3 & 34.0 & 31.6 & 100.0 \\
\hline$(39,1)$ & 0.0 & 0.0 & 0.0 & 0.0 & 0.0 & 0.0 & 0.0 & 100.0 & 100.0 \\
\hline
\end{tabular}

\section{Conclusion}

In this paper, we study the joint decisions of labor supply and use of formal paid care arrangements by mothers of young children in France using a structural model inspired from Ribar (1995). Heterogeneity of the female labor force is clearly illustrated by simulations of economic policy. For example, women working half-time and women working $80 \%$ part-time appear to be very different. The first group of women would not participate if they could. When their income increase, they drop out of the labor force. In the second group, the choice of not working full-time seems more often to be the result from an optimization; would incentives to take part-time jobs disappear, these women would still participate and work full-time.

The lessons from our simulated policy reforms are of several orders. Firstly, the suppression of the tax cut for child care (the French equivalent of the CDCTC) would have very limited effects on paid care use and on the total labor supply of mothers. Secondly, the suppression of the APE (or of part of it) would have huge effects on female labor supply and on paid care use. The simulation of policy reforms we undertake confirms the importance of modeling both the intensive and extensive decisions of labor supply to study those issues. 
This study is not exempt from shortcomings, related both to the data we use and to the model we select. The principal limit imposed by the data is the absence of information on the volume of hours of child care, which prevents us from decomposing child care expenditures into prices and quantities, and finally to estimate a true demand function for hours of care. The expenditures we take into account are only a small fraction of this gross cost, and as a consequence it is not very surprising that the effects we uncover are weak. Another limit of the model, common to the majority of existing studies, is the absence of modeling the supply of child care services, and more generally of general equilibrium effects. In our framework, supply constraints are proxied by a local rate of equipment in day-care centers and childminders, but this variable is taken as exogenous. The fact that the greatest part of the gross expenditures of child care is paid by other actors than the households (the Government and municipalities mostly) has an effect on the supply of collective child care services (e.g. on the construction of new day-care centers). It is clear that the suppression of whole or part of these subsidies would have, beyond the effects highlighted here, also a negative aggregate effect on supply.

Constraints on the job market are taken into account in the same way via the introduction of the local unemployment rate as an exogenous regressor in the coefficient of leisure in the utility function. However, we also consider unemployment as a potential consequence of insufficient productivity, via the introduction of the minimum wage, which, in this field of research, had never been done.

Lastly, our model is static, although in many aspects both labor supply and use of paid child care can be thought of as dynamic processes. Moreover, independently of financial incentives, fertility decisions during the life cycle can introduce a dynamic aspect into the problem of labor supply of women.

\section{References}

[1] Averett, S., E. Peters, D. Waldman (1997), 'Tax Credits, Labor Supply, and Child Care', The Review of Economics and Statistics, 125-135

[2] Andrén, T. (2002), 'A Structural Model of Childcare, Welfare and the Labor Supply of Single Mothers', mimeo.

[3] Blau, D., Hagy A. (1998), 'The Demand for Quality in Child Care', Journal of Political Economy, 106(1): 104-146

[4] Blau, D., P. Robins (1988), 'Child Care Costs and Family Labor Supply', The Review of Economics and Statistics, 70: 374-381

[5] Blundell, R., A. Duncan, J. McCrae, C. Meghir (2000), 'Evaluating In-Work Benefit Reform: The Working Families Tax Credit in the UK', mimeo.

[6] Blundell, R., T. MaCurdy (1999), 'Labor Supply: A Review of Alternative Approaches', ch. 27, Handbook of Labor Economics, 3, O; Ashenfelter and D. Card; ed., Elsevier North Holland.

[7] Choné, P. (2002), 'Une analyse de la participation des couples à la force de travail', Revue économique, 53(6), Novembre 2002. 
[8] Cleveland, G., M. Gunderson, D. Hyatt (1996), 'Child Care Costs and the Employment Decision of Women: Canadian Evidence', Canadian Journal of Economics, 29(1): 132-151

[9] Cleveland, G., D. Hyatt (1993), 'Determinants of Child Care Choices: A Comparison of Ontario and Quebec', Canadian Journal of Regional Science, 16(1): 53-67

[10] Connelly, R., J. Kimmel (2000), 'Marital Status and Full-time/Part-time Work Status in Child Care Choices', mimeo.

[11] Connelly, R. (1992), 'The Effect of Child Care Costs on Married Women's Labor Force Participation', The Review of Economics and Statistics, 74, 83-90.

[12] Del Boca, D. (2002) 'The Effect of Child Care and part time opportunities in participation and fertility decisions in Italy', Journal of Population Economics, 15, 549-573.

[13] Flipo, A., B. Sédillot (2000), 'Le recours aux services payants pour la garde de jeunes enfants se développe', France portrait social, 2000-2001, Insee.

[14] Gouriéroux, C., A. Monfort (1996), Simulation-Based Econometric Methods, CORE Lectures, Oxford University Press.

[15] Guillot, O. (1996), 'Activité féminine et garde des jeunes enfants: une analyse microéconométrique', Economie et prévisions, 122,83-94.

[16] Heckman, J. (1974), 'Effects of Child-Care Programs on Women's Work Effort', the Journal of Political Economy, 82,153-161.

[17] Keane M.P., R.A. Moffit (1998), 'A Structural Model of Multiple Welfare Program Participation and Labor Supply', International Economic Review, 39, 3, August.

[18] Lanot, G., J. M. Robin (1997), 'Participation des femmes au marché du travail en présence de taxation directe et de coûts de participation', Annales d'économie et de statistique, 48.

[19] Laroque, G., B. Salanié (2000), 'une décomposition du non-emploi en France', Economie et Statistique, 331, 47-66.

[20] Laroque, G., B. Salanié (2002), Institutions et emploi, le marché du travail des femmes en France, Economica.

[21] Leprince, F. (2003), 'L'accueil des jeunes enfants en France, Etat des lieux et pistes d'amélioration, rapport pour le Haut Conseil à la Population et à la Famille', La documentation française.

[22] Michalopoulos, C., P. Robins (2002), 'Employment and Child-Care Choices of Singleparent Families in Canada and the United States', Journal of Population Economics, 15, 465-493.

[23] Michalopoulos, C., P. Robins (2000), 'Employment and Child-Care Choices in Canada and the United States', Canadian Journal of Economics, 33(2): 435-470

[24] Michalopoulos, C., P. Robins, I. Garfinkel (1992), 'A Structural Model of Labor Supply and Child Care Demand', Journal of Human Resources, 27: 166-203. 
[25] Piketty, T. (1998), 'L'impact des incitations financières au travail sur les comportements individuels: une estimation pour le cas français', Economie et Prévision, 132-133, 1-35.

[26] Powell, L. (2002), 'Joint Labor Supply and Childcare Choice Decisions of Married Mothers', The Journal of Human Resources, 37(1): 106-128.

[27] Powell, L. (1997), 'The Impact of Child Care Costs on the Labour Supply of Married Mothers: Evidence from Canada', Canadian Journal of Economics, 30(3): 577-593.

[28] Ribar, D. (1995), 'A Structural Model of Child Care and the Labor Supply of Married Women', Journal of Labor Economics, 13(3): 558-597

[29] Robert-Bobée, I. (2002), 'Des coûts de garde d'enfants parfois élevés malgré des aides publiques importantes', Données Sociales, Insee. 


\section{APPENDIX}

In the sequel, $\varphi$ and $\Phi$ denote respectively the density and the cumulative density function (cdf) of the standard normal law, ' 2 and _ 2 denote the density and the cdf of the standard bivariate normal law.

\section{A Simulation method}

We use a straightforward extension of the GHK method (see e.g. Gouriéroux and Monfort, 1996, pages 98 and 105) which allows one to obtain an unbiased simulator of $E\left[h(v) 1_{v \in D}\right]$, where $\mathrm{h}$ is an integrable function, $\mathrm{D}$ is a rectangular domain, and $v$ is a normal vector with law $\mathrm{N}(0, \Sigma)$.

In each of the eight possible states of the model, we denote $\Sigma$ the variance of unobserved residuals conditional on the set of observed variables. Our generic problem 20 is to compute expectations of the type $E\left[h(v) 1_{v \in D}\right]$, where $\mathrm{v}$ is a normal vector with law $\mathrm{N}(0, \Sigma)$, h is a given function easy to evaluate, and the domain $\mathrm{D}$ is defined by a system of constraints of the following type:

$$
\begin{gathered}
A_{1} \leq v_{1} \leq B_{1} \\
A_{2}\left(v_{1}\right) \leq v_{2} \leq B_{2}\left(v_{1}\right) .
\end{gathered}
$$

In this system, $A_{1}$ and $B_{1}$ are constants, whereas $A_{2}$ is a function of $v_{1}$. Therefore, $D$ is not a rectangular domain, but rather a lower triangular one.

We denote $C$ the (lower triangular) Cholesky matrix of $\Sigma$ (so that $\Sigma=\mathrm{CC}$ '). The vector $u$ defined by $v=C u$ follows $\mathrm{N}(0, \mathrm{I})$. As $C$ is lower triangular, the preceding system of constraints expressed as a function of $\mathrm{u}$ is still lower triangular:

$$
\begin{gathered}
\widetilde{A}_{1} \leq u_{1} \leq \widetilde{B}_{1} \\
\widetilde{A}_{2}\left(u_{1}\right) \leq u_{2} \leq \widetilde{B}_{2}\left(u_{1}\right) .
\end{gathered}
$$

These constraints define a domain $D^{*}$ in the $\left(u_{1}, u_{2}\right)$ plane. Let us draw $u_{1}^{s}$ in $\mathrm{N}(0,1)$ truncated to $\left[\widetilde{A}_{1}, \widetilde{B}_{1}\right]$ and $u_{2}^{s}$ in $\mathrm{N}(0,1)$ truncated to $\left[\widetilde{A}_{2}\left(u_{1}^{s}\right), \widetilde{B}_{2}\left(u_{1}^{s}\right)\right]$. Then, an unbiased simulator of $E\left[h(v) 1_{v \in D}\right]$ is $h\left(C u^{s}\right) \tilde{p}\left(u_{1}^{s}\right)$ with

$$
\widetilde{p}\left(u_{1}^{s}\right)=\left[\Phi\left(\widetilde{B}_{1}\right)-\Phi\left(\widetilde{A}_{1}\right)\right] \cdot\left[\Phi\left(\widetilde{B}_{2}\left(u_{1}^{s}\right)\right)-\Phi\left(\widetilde{A}_{2}\left(u_{1}^{s}\right)\right)\right]
$$

Indeed, the joint density of $u^{s}=\left(u_{1}^{s}, u_{2}^{s}\right)$ is $g(x)=1_{D^{*}} \cdot \varphi\left(x_{1}\right) \cdot \varphi\left(x_{2}\right) \cdot / \tilde{p}\left(x_{1}\right)$ and we have:

$$
\begin{aligned}
E\left[h\left(C u^{s}\right) \tilde{p}\left(u_{1}^{s}\right)\right] & =\int h(C x) 1_{D^{*}} \cdot \varphi\left(x_{1}\right) \cdot \varphi\left(x_{2}\right) \cdot d x_{1} d x_{2} \\
& =E\left[h(C u) 1_{D^{*}}(u)\right] \\
& =E\left[h(v) 1_{D}(v)\right]
\end{aligned}
$$

\footnotetext{
${ }^{20}$ In this section, we work in dimension 2 . The argument extends easily to higher dimensions.
} 
If we draw $S$ realizations of the vector $u^{s}$ the expectation $E\left[h(v) 1_{v \in D}\right]$ is estimated as

$$
\frac{1}{S} \sum_{s=1}^{S} \widetilde{p}\left(u_{1}^{s}\right) h\left(C u^{s}\right)
$$

For the estimations presented in the text, we used $S=50$. In practice, we observed that beyond $S=20$, the results hardly vary with $S$.

\section{B Likelihood of the model}

In this section, we denote $w^{*}$ and $D^{*}$ as the variables describing wage and child care expenditure, to distinguish the variables from their realizations $w$ and $d$. Recalling the latent model:

$$
\left\{\begin{array}{lc}
\ln w^{*}=x_{w} \gamma_{w}+\varepsilon_{w} & \text { (wage equation) } \\
\ln D^{*}=x_{d} \gamma_{d}+\varepsilon_{d} & \text { (formal child care expenditure equation) }
\end{array}\right.
$$

The utility of the household writes:

$$
\begin{array}{r}
U(c, h, f)=c+\beta_{h} h+\beta_{f} f+\beta_{c c} c^{2}+\beta_{c h} c h+\beta_{h h} h^{2}+\beta_{f h} f h, \\
\text { with }\left\{\begin{array}{l}
\beta_{h}=x_{h} \gamma_{h}+\varepsilon_{h} \\
\beta_{f}=x_{f} \gamma_{f}+\varepsilon_{f}
\end{array}\right.
\end{array}
$$

The vector of the residuals $\left(\varepsilon_{w}, \varepsilon_{f}, \varepsilon_{d}, \varepsilon_{h}\right)$ is supposed to be normal with mean zero and unrestricted covariance matrix $\Sigma$.

$H$ can take only 4 values $(0,20,30,39)$ and $F$ can take only two values $(0,1)$ so that crossing $f$ and $h$ defines eight states: $(0,0),(0,20),(0,30),(0,39),(1,0),(1,20),(1,30),(1,39)$.

Wages are observed only when the woman works, and child care expenditures are observed only when the woman uses paid child care.

The problem is to choose the state that maximizes households' utility under the relevant budget constraint. Exceptions are women whose productivity is under the minimum wage who are set not to work. Their choice is limited to the states $(0,0)$ and $(0,1)$. The budget constraint depends, among other things, on the wage and the care expenditures.

Denoting $U_{h f}$ utility in state $(H=h, F=f)$, we have $U_{h f}=V_{h f}+h \varepsilon_{h}+f \varepsilon_{f}$. Then

$$
\begin{array}{cccc}
U_{0,0}=V_{0,0} & U_{0,20}=V_{0,20}+20 \varepsilon_{h} & U_{0,30}=V_{0,30}+30 \varepsilon_{h} & U_{0,39}=V_{0,39}+39 \varepsilon_{h} \\
U_{1,0}=V_{1,0}+\varepsilon_{f} & U_{1,20}=V_{1,20}+20 \varepsilon_{h}+\varepsilon_{f} & U_{1,30}=V_{1,30}+30 \varepsilon_{h}+\varepsilon_{f} & U_{1,39}=V_{1,39}+39 \varepsilon_{h}+\varepsilon_{f}
\end{array}
$$

Differences in the utility between states depend always on unobserved residuals between utility, which is consistent to our data: in the sample, the 8 states are possible, including the case to use paid child care while non-working 21 .

The utility level $V_{0,0}$ does not contain unobserved residuals, and thus can be calculated once for all (conditional on the current value of the parameters) for all individuals of the sample. The other quantities $V_{h f}$ contain unobserved residuals, and have to be calculated within each simulation.

\footnotetext{
${ }^{21}$ Ribar (1995) puts heterogeneity on the coefficients $\beta_{f h}$ and $\beta_{h}$. As a consequence, $U_{0,0}-U_{0,1}$ is not random and Ribar has to assume that the state $(0,1)$ is impossible and to exclude such observations from the sample.
} 
We denote by $\underline{\varepsilon}_{w}$ the (individual) value of $\varepsilon_{w}$ such that the productivity of the woman calculated for this value of $\varepsilon_{w}$ is equal to the minimum wage.

The probabilities of the eight states $(h, f)$ define domains like those introduced above in the description of the simulation method (Appendix A).

\section{State $(\mathbf{0 , 0})$}

In this state, as in state $(0,1)$, the woman does not work. This may have two reasons: either her productivity is too low $\left(\varepsilon_{w}<\underline{\varepsilon}_{w}\right)$, or her productivity would allow her to work, but the $(0,0)$ situation is optimal among the eight possible choices. $\varepsilon_{d}$ and $\varepsilon_{w}$ are not observed. The likelihood thus writes $L_{0,0}=L_{0,0,1}+L_{0,0,2}$ with

$$
\begin{gathered}
L_{0,0,1}=P\left[\begin{array}{c}
-\infty<\varepsilon_{w} \leq \underline{\varepsilon}_{w} \\
-\infty<\varepsilon_{d}<+\infty \\
\varepsilon_{f} \leq V_{0,0}-V_{0,1}\left(\varepsilon_{d}\right)
\end{array}\right] \\
\underline{\varepsilon}_{w} \leq \varepsilon_{w}<+\infty \\
-\infty<\varepsilon_{d}<+\infty \\
L_{0,0,2}=P\left[\begin{array}{c}
\varepsilon_{h} \leq \min \left(\frac{V_{0,0}-V_{20,0}}{20}, \frac{V_{0,0}-V_{30,0}}{30}, \frac{V_{0,0}-V_{39,0}}{39}\right) \\
\varepsilon_{f} \leq V_{0,0}+\min \left(-V_{0,1},-V_{20,1}-20 \varepsilon_{h},-V_{30,1}-30 \varepsilon_{h},-V_{39,1}-39 \varepsilon_{h}\right)
\end{array}\right]
\end{gathered}
$$

\section{States $(20,0),(30,0)$ and $(39,0)$}

In the state $(20,0)$, as in the states $(30,0)$ and $(39,0)$, the woman works but does not use paid child care. Thus, $\varepsilon_{d}$ is unobserved, $\varepsilon_{w}$ is known. The likelihood writes:

$$
\begin{gathered}
L_{20,0}=\frac{1}{\sigma_{w}} \cdot \varphi\left(\frac{\ln w-x_{w} \gamma_{w}}{\sigma_{w}}\right) \cdot P_{20,0} \\
\text { with } P_{20,0}=P\left[\begin{array}{c}
-\infty<\varepsilon_{d}<+\infty \\
\frac{V_{0,0}-V_{20,0}}{20} \leq \varepsilon_{h} \leq \min \left(\frac{V_{20,0}-V_{30,0}}{10}, \frac{V_{20,0}-V_{39,0}}{19}\right) \\
\varepsilon_{f} \leq V_{20,0}+\min \left(-V_{0,1}+20 \varepsilon_{h},-V_{20,1},-V_{30,1}-10 \varepsilon_{h},-V_{39,1}-19 \varepsilon_{h}\right. \\
\operatorname{sachant} \varepsilon_{w}=\ln w-x_{w} \gamma_{w}
\end{array}\right]
\end{gathered}
$$

This is similar for the 2 other states. 


\section{State $(\mathbf{0 , 1})$}

Proceeding in the same way as for the $(0,0)$ case, we get $L_{0,1}=L_{0,1,1}+L_{0,1,2}$ with

$$
L_{0,1,1}=\frac{1}{\sigma_{d}} \cdot \varphi\left(\frac{\ln d-x_{d} \gamma_{d}}{\sigma_{d}}\right) \cdot P\left[\begin{array}{c}
-\infty<\varepsilon_{w} \leq \underline{\varepsilon}_{w} \\
-\varepsilon_{f} \leq V_{0,1}\left(\varepsilon_{d}\right)-V_{0,0} \\
\text { sachant } \varepsilon_{d}=\ln d-x_{d} \gamma_{d}
\end{array}\right]
$$

and

$$
L_{0,1,2}=\frac{1}{\sigma_{d}} \cdot \varphi\left(\frac{\ln d-x_{d} \gamma_{d}}{\sigma_{d}}\right) \cdot P\left[\begin{array}{c}
\underline{\varepsilon}_{w} \leq \varepsilon_{w} \leq \infty \\
\varepsilon_{h} \leq \min \left(\frac{V_{0,1}-V_{20,1}}{20}, \frac{V_{0,1}-V_{30,1}}{30}, \frac{V_{0,1}-V_{39,1}}{39}\right) \\
\varepsilon_{f} \geq \max \left(V_{0,0}, V_{20,0}+20 \varepsilon_{h}, V_{30,0}+30 \varepsilon_{h}, V_{39,0}+39 \varepsilon_{h}\right)-V_{0,1} \\
\text { sachant } \varepsilon_{d}=\ln d-x_{d} \gamma_{d}
\end{array}\right]
$$

\section{States $(20,1),(30,1)$ and $(39,1)$}

In these states, the woman works and uses paid child care. Then, for a given value of the parameters of the model, the residuals $\varepsilon_{w}$ and $\varepsilon_{d}$ are known, and the likelihood for the state $(20,1)$ writes in the following manner:

$$
L_{20,1}=\frac{1}{\sigma_{d}} \cdot \frac{1}{\sigma_{w}} \cdot \varphi_{2}\left(\frac{\ln d-x_{d} \gamma_{d}}{\sigma_{d}}, \frac{\ln w-x_{w} \gamma_{w}}{\sigma_{w}}, \rho_{w d}\right) \cdot P_{20,1}
$$

where $P_{20,1}=P\left[\begin{array}{c}\frac{V_{0,1}-V_{20,1}}{20} \leq \varepsilon_{h} \leq \min \left(\frac{V_{20,1}-V_{30,1}}{10}, \frac{V_{20,1}-V_{39,1}}{19}\right) \\ \varepsilon_{f} \geq \max \left(V_{0,0}-20 \varepsilon_{h}, V_{20,0}, V_{30,0}+10 \varepsilon_{h}, V_{39,0}+19 \varepsilon_{h}\right)-V_{20,1} \\ \text { sachant } \varepsilon_{d}=\ln d-x_{d} \gamma_{d} \text { et } \varepsilon_{w}=\ln w-x_{w} \gamma_{w}\end{array}\right]$

It is similar for the states $(30,1)$ and $(39,1)$. In those three cases, the probability involving the preference residuals can be written as one-dimensional integrals with respect to $\varepsilon_{h}$ thanks to the conditioning properties of the normal law. These integrals are computed numerically using a Gauss-Legendre quadrature. For states $(20,1)$ and $(30,1)$, a problem can appear in the course of the maximization routine, because for a non-optimal value of the parameters, nothing guarantees that the integral bounds are correctly ordered. When this is not the case, negative probabilities show up. To bypass this difficulty, we choose to smooth the estimated probabilities by returning a very small positive number when the computed probability is negative, and (nearly) the computed value when it is positive. Near the optimum, the bounds are correctly ordered for all observations, and the smoothing has no effect. 


\section{CESifo Working Paper Series}

(for full list see www.cesifo.de)

994 Louis N. Christofides and Chen Peng, Contract Duration and Indexation in a Period of Real and Nominal Uncertainty, July 2003

995 M. Hashem Pesaran, Til Schuermann, Björn-Jakob Treutler, and Scott M. Weiner, Macroeconomic Dynamics and Credit Risk: A Global Perspective, July 2003

996 Massimo Bordignon and Sandro Brusco, On Enhanced Cooperation, July 2003

997 David F. Bradford, Addressing the Transfer-Pricing Problem in an Origin-Basis X Tax, July 2003

998 Daniel Gros, Who Needs Foreign Banks?, July 2003

999 Wolfram Merzyn and Heinrich W. Ursprung, Voter Support for Privatizing Education: Evidence on Self-Interest and Ideology, July 2003

1000 Jo Thori Lind, Fractionalization and the Size of Government, July 2003

1001 Daniel Friedman and Donald Wittman, Litigation with Symmetric Bargaining and TwoSided Incomplete Information, July 2003

1002 Matthew Clarke and Sardar M. N. Islam, Health Adjusted GDP (HAGDP) Measures of the Relationship Between Economic Growth, Health Outcomes and Social Welfare, July 2003

1003 Volker Grossmann, Contest for Attention in a Quality-Ladder Model of Endogenous Growth, August 2003

1004 Marcel Gérard and Joan Martens Weiner, Cross-Border Loss Offset and Formulary Apportionment: How do they affect multijurisdictional firm investment spending and interjurisdictional tax competition ?, August 2003

1005 Burkhard Heer, Nonsuperneutrality of Money in the Sidrauski Model with Heterogeous Agents, August 2003

1006 V. Anton Muscatelli, Piergiovanna Natale, and Patrizio Tirelli, A Simple and Flexible Alternative to the Stability and Growth Pact Deficit Ceilings. Is it at hand?, August 2003

1007 Reto Foellmi and Josef Zweimüller, Inequality and Economic Growth: European Versus U.S. Experiences, August 2003

1008 James S. Costain and Michael Reiter, Business Cycles, Unemployment Insurance, and the Calibration of Matching Models, August 2003 
1009 Marco Runkel, Optimal Contest Design when the Designer's Payoff Depends on Competitive Balance, August 2003

1010 Donald O. Parsons, Torben Tranaes and Helene Bie Lilleør, Voluntary Public Unemployment Insurance, August 2003

1011 Rüdiger Pethig and Andreas Wagener, Profit Tax Competition and Formula Apportionment, August 2003

1012 Johan Willner, Privatisation and Public Ownership in Finland, August 2003

1013 Seppo Kari and Jouko Ylä-Liedenpohja, Taxation and Valuation of International Real Investments, August 2003

1014 James Heckman, Rosa Matzkin and Lars Nesheim, Simulation and Estimation of Hedonic Models, August 2003

1015 Biswa N. Bhattacharyay, Towards a Macro-Prudential Leading Indicators Framework for Monitoring Financial Vulnerability, August 2003

1016 J. Stephen Ferris and Stanley L. Winer, Searching for Keynes: With Application to Canada, 1870-2000, August 2003

1017 Massimo Bordignon, Luca Colombo and Umberto Galmarini, Fiscal Federalism and Endogenous Lobbies’ Formation, August 2003

1018 Annette Alstadsæter, The Dual Income Tax and Firms’ Income Shifting through the Choice of Organizational Form and Real Capital Investments, August 2003

1019 Peter Fredriksson and Bertil Holmlund, Optimal Unemployment Insurance Design: Time Limits, Monitoring, or Workfare?, August 2003

1020 Kashif S. Mansori, Following in their Footsteps: Comparing Interest Parity Conditions in Central European Economies to the Euro Countries, August 2003

1021 Christoph Borgmann and Matthias Heidler, Demographics and Volatile Social Security Wealth: Political Risks of Benefit Rule Changes in Germany, August 2003

1022 Kjell Erik Lommerud, Bjørn Sandvik and Odd Rune Staume, Good Jobs, Bad Jobs and Redistribution, August 2003

1023 Patrick Karl O’Brien, The Governance of Globalization: The Political Economy of Anglo-American Hegemony, 1793-2003, September 2003

1024 Antonio Ciccone and Giovanni Peri, Skills' Substitutability and Technological Progress: U.S. States 1950-1990, September 2003

1025 Bjørn Sandvik, Optimal Taxation and Normalisations, September 2003 
1026 Massimo Bordignon and Gilberto Turati, Bailing Out Expectations and Health Expenditure in Italy, September 2003

1027 José A. Herce, Namkee Ahn, Ricard Génova, and Joaquín Pereira, Bio-Demographic and Health Aspects of Ageing in the EU, September 2003

1028 John Komlos and Marieluise Baur, From the Tallest to (One of) the Fattest: The Enigmatic Fate of the American Population in the $20^{\text {th }}$ Century, September 2003

1029 Stefan Napel and Mika Widgrén, Bargaining and Distribution of Power in the EU's Conciliation Committee, September 2003

1030 Kai Li and Dale J. Poirier, Relationship Between Maternal Behavior During Pregnancy, Birth Outcome, and Early Childhood Development: An Exploratory Study, September 2003

1031 Ivar Ekeland, James J. Heckman, and Lars Nesheim, Identifcation and Estimation of Hedonic Models, September 2003

1032 Kjetil Bjorvatn and Alexander W. Cappelen, Decentralization and the Fate of Minorities, September 2003

1033 Lars-Erik Borge and Jørn Rattsø, The Relationships Between Costs and User Charges: The Case of a Norwegian Utility Service, September 2003

1034 Maureen Were and Nancy N. Nafula, An Assessment of the Impact of HIV/AIDS on Economic Growth: The Case of Kenya, September 2003

1035 A. Lans Bovenberg, Tax Policy and Labor Market Performance, September 2003

1036 Peter Birch Sørensen, Neutral Taxation of Shareholder Income: A Norwegian Tax Reform Proposal, September 2003

1037 Roberta Dessi and Sheilagh Ogilvie, Social Capital and Collusion: The Case of Merchant Guilds, September 2003

1038 Alessandra Casarico and Carlo Devillanova, Capital-skill Complementarity and the Redistributive Effects of Social Security Reform, September 2003

1039 Assaf Razin and Efraim Sadka, Privatizing Social Security Under Balanced-Budget Constraints: A Political-Economy Approach, September 2003

1040 Michele Moretto, Paolo M. Panteghini, and Carlo Scarpa, Investment Size and Firm’s Value under Profit Sharing Regulation, September 2003

1041 A. Lans Bovenberg and Peter Birch Sørensen, Improving the Equity-Efficiency Tradeoff: Mandatory Savings Accounts for Social Insurance, September 2003

1042 Bas van Aarle, Harry Garretsen, and Florence Huart, Transatlantic Monetary and Fiscal Policy Interaction, September 2003 
1043 Jerome L. Stein, Stochastic Optimal Control Modeling of Debt Crises, September 2003

1044 Thomas Stratmann, Tainted Money? Contribution Limits and the Effectiveness of Campaign Spending, September 2003

1045 Marianna Grimaldi and Paul De Grauwe, Bubbling and Crashing Exchange Rates, September 2003

1046 Assar Lindbeck and Dennis J. Snower, The Firm as a Pool of Factor Complementarities, September 2003

1047 Volker Grossmann, Firm Size and Diversification: Asymmetric Multiproduct Firms under Cournot Competition, September 2003

1048 Dan Anderberg, Insiders, Outsiders, and the Underground Economy, October 2003

1049 Jose Apesteguia, Steffen Huck and Jörg Oechssler, Imitation - Theory and Experimental Evidence, October 2003

1050 G. Abío, G. Mahieu and C. Patxot, On the Optimality of PAYG Pension Systems in an Endogenous Fertility Setting, October 2003

1051 Carlos Fonseca Marinheiro, Output Smoothing in EMU and OECD: Can We Forego Government Contribution? A Risk Sharing Approach, October 2003

1052 Olivier Bargain and Nicolas Moreau, Is the Collective Model of Labor Supply Useful for Tax Policy Analysis? A Simulation Exercise, October 2003

1053 Michael Artis, Is there a European Business Cycle?, October 2003

1054 Martin R. West and Ludger Wößmann, Which School Systems Sort Weaker Students into Smaller Classes? International Evidence, October 2003

1055 Annette Alstadsaeter, Income Tax, Consumption Value of Education, and the Choice of Educational Type, October 2003

1056 Ansgar Belke and Ralph Setzer, Exchange Rate Volatility and Employment Growth: Empirical Evidence from the CEE Economies, October 2003

1057 Carsten Hefeker, Structural Reforms and the Enlargement of Monetary Union, October 2003

1058 Henning Bohn and Charles Stuart, Voting and Nonlinear Taxes in a Stylized Representative Democracy, October 2003

1059 Philippe Choné, David le Blanc and Isabelle Robert-Bobée, Female Labor Supply and Child Care in France, October 2003 